\title{
Novel inhibitor candidates of TRPV2 prevent damage of dystrophic myocytes and ameliorate against dilated cardiomyopathy in a hamster model
}

\author{
Yuko Iwata1, Yoshimi Katayama², ${ }^{2,}$ Yasushi Okuno ${ }^{3}$ and Shigeo Wakabayashi ${ }^{4,6}$ \\ ${ }^{1}$ Departments of Molecular Physiology and Clinical Research, National Cerebral and Cardiovascular Center Research Institute, \\ Suita, Osaka, Japan \\ ${ }^{2}$ Pharmacological Research Laboratories, Drug Safety Testing Center Co., Ltd., Higashimatsuyama, Saitama, Japan \\ ${ }^{3}$ Department of Clinical System Onco-Informatics, Graduate School of Medicine, Kyoto University, Kyoto, Japan \\ ${ }^{4}$ Departments of Molecular Physiology and Cardiac Physiology, National Cerebral and Cardiovascular Center Research \\ Institute, Suita, Osaka, Japan \\ ${ }^{5}$ Present affiliation: Biological Research Laboratories, Nissan Chemical Industries, Ltd, Shiraoka, Saitama, Japan \\ ${ }^{6}$ Present affiliation: Department of Pharmocology, Osaka Medical Collage, Takatsuki, Osaka, Japan \\ Correspondence to: Yuko Iwata, email: yukoiwat@ncvc.go.jp \\ Keywords: cardiomyopathy; muscular dystrophy; $\mathrm{Ca}^{2+}$ influx; $\mathrm{Ca}^{2+}$-permeable channel; therapy; Gerotarget \\ Received: January 26, 2018 Accepted: February 01, 2018 Epub: February 08, 2018 Published: March 06, 2018 \\ Copyright: Iwata et al. This is an open-access article distributed under the terms of the Creative Commons Attribution License 3.0 \\ (CC BY 3.0), which permits unrestricted use, distribution, and reproduction in any medium, provided the original author and source \\ are credited.
}

\section{ABSTRACT}

Transient receptor potential cation channel, subfamily $\mathbf{V}$, member $\mathbf{2}$ (TRPV2) is a principal candidate for abnormal $\mathrm{Ca}^{2+}$-entry pathways, which is a potential target for therapy of muscular dystrophy and cardiomyopathy. Here, an in silico drug screening and the following cell-based screening to measure the TRPV2 activation were carried out in HEK293 cells expressing TRPV2 using lead compounds (tranilast or SKF96365) and off-patent drug stocks. We identified 4 chemical compounds containing aminobenzoyl groups and 1 compound (lumin) containing an ethylquinolinium group as candidate TRPV2 inhibitors. Three of these compounds inhibited $\mathrm{Ca}^{2+}$ entry through both mouse and human TRPV2, with IC $_{50}$ of less than $10 \mu \mathrm{M}$, but had no apparent effect on other members of TRP family such as TRPV1 and TRPC1. Particularly, lumin inhibited agonist-induced TRPV 2 channel activity at a low dose. These compounds inhibited abnormally increased $\mathrm{Ca}^{2+}$ influx and prevented stretch-induced skeletal muscle damage in cultured myocytes from dystrophic hamsters (J2N-k). Further, they ameliorated cardiac dysfunction, and prevented disease progression in vivo in the same J2N-k hamsters developing dilated cardiomyopathy as well as muscular dystrophy. The identified compounds described here are available as experimental tools and represent potential treatments for patients with cardiomyopathy and muscular dystrophy.

\section{INTRODUCTION}

Dilated cardiomyopathy (DCM) is a severe disorder characterised by ventricular dilation and cardiac dysfunction [1-3]. A subset of familial DCM is caused by mutations in genes encoding components of the dystrophin-glycoprotein complex [4-6], a multi-subunit complex $[5,7,8]$ spanning the sarcolemma that links the extracellular matrix to the actin cytoskeleton [9].
Disruption of the dystrophin-glycoprotein complex can significantly compromise membrane integrity and stability during muscle contraction/relaxation and reduce myocyte survival. Enhanced susceptibility to muscle damage is observed in dystrophic animals, such as dystrophindeficient $m d x$ mice and $\delta$-sarcoglycan (SG)-deficient J2N-k hamsters, which exhibit cardiac and skeletal abnormalities similar to those observed in human patients with Duchenne or limb-girdle muscular dystrophy. 
Chronic elevation in cytosolic $\mathrm{Ca}^{2+}$ concentration $\left(\left[\mathrm{Ca}^{2+}\right]_{\mathrm{i}}\right)$ beneath the sarcolemma and within other cellular compartments has been reported in skeletal muscle fibres and cultured myotubes derived from Duchenne muscular dystrophy patients and $m d x$ mice $[10-12] .\left[\mathrm{Ca}^{2+}\right]_{i}$ in muscle fibre cells is regulated by multiple $\mathrm{Ca}^{2+}$-permeable channels, $\mathrm{Ca}^{2+}$ pumps, and transporters in the plasma membrane and sarcoplasmic reticulum, among which sarcolemmal $\mathrm{Ca}^{2+}$-permeable channels (also known as $\mathrm{Ca}^{2+}$-specific leak channels) and mechanosensitive, nonselective cation channels contribute to abnormal $\mathrm{Ca}^{2+}$ handling in dystrophic myocytes $[13,14]$. We previously showed that $\delta$-SG-deficient myocytes are highly susceptible to mechanical stretch and enhanced $\mathrm{Ca}^{2+}$ influx via the stretch-activated nonselective $\mathrm{Ca}^{2+}$ channel [15] and identified transient receptor potential cation channel, subfamily V (vanilloid), member 2 (TRPV2) as a candidate factor in $\mathrm{Ca}^{2+}$ entry pathways whose activation results in perturbation of $\mathrm{Ca}^{2+}$ handling and subsequent muscular degeneration [16]. The critical role of TRPV2 in muscular dystrophy was demonstrated using a dominantnegative strategy $[17,18]$. Furthermore, sarcolemmal staining of TRPV2 was increased in heart cells from cardiomyopathic J2N-k hamsters. In addition, TRPV2 channel activity was enhanced in $\mathrm{J} 2 \mathrm{~N}-\mathrm{k}$ cardiomyocytes, as evidenced by high $\left[\mathrm{Ca}^{2+}\right]_{\mathrm{i}}$ and the observed 2-aminoethoxydiphenylborate (2-APB)-induced increase in $\left[\mathrm{Ca}^{2+}\right]_{\mathrm{i}}[19]$. Similar increased sarcolemmal staining of TRVP2, as well as heart failure, was observed [19] in studies using murine models of DCM (doxorubicininduced DCM mice and sugar chain abnormal 4C30 DCM mice [20]) and in human patients with idiopathic DCM [19]. We observed that reducing TRPV2 activity was an effective therapeutic strategy for muscular dystrophy and cardiomyopathy $[17,19]$. Moreover, we found that antiallergy agent $\mathrm{N}$-[3,4-dimethoxycinnamonyl]-anthranilic acid (tranilast) inhibited $\mathrm{Ca}^{2+}$ entry through TRPV2 and ameliorated muscle degeneration [19]. 1-[ $\beta-[3-$ (4-methoxyphenyl)propoxy]-4-methoxyphenethyl]-

1H-imidazole (SKF96365) has also been reported to inhibit TRPV family channels [21]. However, because the effective doses of known TRPV2 inhibitors are high $(>10-100 \mu \mathrm{M})$, while the drugs are also relatively unselective, more potent and specific TRPV2 inhibitors are needed to confirm whether TRPV2 is an effective drug target for the treatment of patients with DCM and related disorders.

Here, a high throughput assay was performed to screen a chemical library for potential TRPV2 inhibitors. The TRPV2 agonist 2-APB, which induced a large increase in TRPV2 activity and $\left[\mathrm{Ca}^{2+}\right]_{\mathrm{i}}$ under weak acidic conditions, was used to screen candidate compounds. Several TRPV2 inhibitors were identified using tranilast and SKF96365 (Figure 1) as lead compounds. The beneficial effects of the newly identified TRPV2 inhibitors were assessed in dystrophic/cardiomyopathic hamsters.

\section{RESULTS}

\section{High throughput $\mathrm{Ca}^{2+}$ measurements for TRPV2 inhibitor screening}

For TRPV2 inhibitor screening, we used a cellbased assay system to monitor TRPV2-dependent increases in $\left[\mathrm{Ca}^{2+}\right]_{i}$. We initially assessed several reported TRPV2 agonists, including 2-APB, probenecid, and cannabidiol; however, the $\mathrm{Ca}^{2+}$ responses elicited by these agonists were too small for the purpose of drug screening. Therefore, we aimed to identify conditions suitable for detecting the $\mathrm{Ca}^{2+}$-response elicited by 2 -APB, a widely used TRPV agonist.

HEK293 cells expressing mouse TRPV2 (mTRPV2) and non-transfected HEK293 cells were loaded with fura2-AM and placed in low $\mathrm{CaCl}_{2}$ medium $(0.5 \mathrm{mM})$. When the medium was replaced with high $\mathrm{Ca}^{2+}$ medium $(5 \mathrm{mM})$ at neutral $\mathrm{pH}$ (7.4) containing TRPV agonist 2-APB, the increase in $\left[\mathrm{Ca}^{2+}\right]_{\mathrm{i}}$ was very small (Figure $2 \mathrm{~A}$ ). However, when cells were perfused with weak acidic medium $(\mathrm{pH}$ 6.5), a large increase in $\left[\mathrm{Ca}^{2+}\right]_{\mathrm{i}}$ was detected in TRPV2expressing HEK293 cells. We tested whether low pHdependent 2-APB-induced activation of TRPV2 was also detected in the TRPV2 current measured by the whole cell patch clamp technique. Consistent with the response to $\mathrm{Ca}^{2+}$, low $\mathrm{pH}$ dramatically activated TRPV2 current in the presence of 2-APB (Figure 2B). The observed $\mathrm{pH}$-dependent TRPV2 activation occurred at all tested voltages (Figure $2 \mathrm{C}$ ), indicating a voltage-independent effect. These results indicate that TRPV2 activation by 2-APB is enhanced at low $\mathrm{pH}$.

For the drug screening, we designed a method involving measurement of the $\mathrm{Ca}^{2+}$ response using a 96well high-throughput plate-reader. Cells were placed in low $\mathrm{CaCl}_{2}(0.5 \mathrm{mM})$ medium, which was replaced with high $\mathrm{CaCl}_{2}$ medium $(5 \mathrm{mM})$ with or without the TRPV agonist 2-APB and adjusted to various $\mathrm{pH}$ values. While no effects were observed at neutral extracellular $\mathrm{pH}$, a marked increase in $\left[\mathrm{Ca}^{2+}\right]_{\mathrm{i}}$ was detected under acidic conditions $(\mathrm{pH}<7.0)$, concomitant with a $\mathrm{pH}$ drop from 7.0 to 6.5 (Figure 2D). The dependence of the $\mathrm{Ca}^{2+}$ response on the concentration of 2-APB was evaluated at $5 \mathrm{mM} \mathrm{CaCl}_{2} / \mathrm{pH}$ 6.5. $\left[\mathrm{Ca}^{2+}\right]_{\mathrm{i}}$ increased upon addition of $2-\mathrm{APB}$ in the range of $0.3-1.0 \mathrm{mM}$ (Figure $2 \mathrm{E}$ ). Thus, a screening for drugs effective in acidic medium containing 2-APB and a high (extracellular) $\mathrm{CaCl}_{2}$ was carried out.

\section{TRPV2 inhibitor screening}

Drugs known to inhibit ion transport proteins were tested using the high throughput screening 
system. Exposure to inhibitors of the $\mathrm{Na}^{+} / \mathrm{H}^{+}$exchanger (cariporide), stretch-activated channels (streptomycin), and voltage-gated $\mathrm{Ca}^{2+}$ channels (diltiazem) at concentrations up to $100 \mu \mathrm{M}$ did not inhibit the 2-APBinduced increase in $\left[\mathrm{Ca}^{2+}\right]_{\mathrm{i}}$ in HEK293 cells expressing mTRPV2 (Figure 2F). The nonselective cation channel blockers tranilast and SKF96365 [22, 23] had an inhibitory effect on the 2-APB-induced increase in $\left[\mathrm{Ca}^{2+}\right]_{i}$

Tranilast<smiles>COc1ccc(/C=C/C(=O)Nc2ccccc2C(=O)O)cc1OC</smiles>

A3<smiles>COc1cc(C=C(C#N)C(=O)Nc2ccccc2C(=O)O)cc(Cl)c1OC</smiles>

SKF96365<smiles>COc1ccc(CCCOC(Cn2ccnc2)c2ccc(OC)cc2)cc1</smiles>

in HEK293 cells expressing mTRPV2 at high doses $\left(\mathrm{IC}_{50} \geq 10 \mu \mathrm{M}\right)$. Using tranilast and SKF96365 as lead compounds, 350 drug candidates were selected from the chemical library and classified as series A or B, respectively. The 350 drug candidates were screened for the ability to inhibit $\mathrm{Ca}^{2+}$ entry through TRPV2 at a low concentration. A3, A48, A63, and B6 (See Figure 1 and materials and methods for chemical structure) inhibited

\section{A48}<smiles>COc1ccc(C(=O)Nc2c(C)cccc2C(=O)O)cc1</smiles>

A63<smiles>COc1ccc(/C=C/C(=O)Nc2ccccc2[N+](=O)[O-])cc1OC</smiles><smiles>COc1cccc(OCCn2cc(/C=N/n3cnnc3)c3ccccc32)c1</smiles>

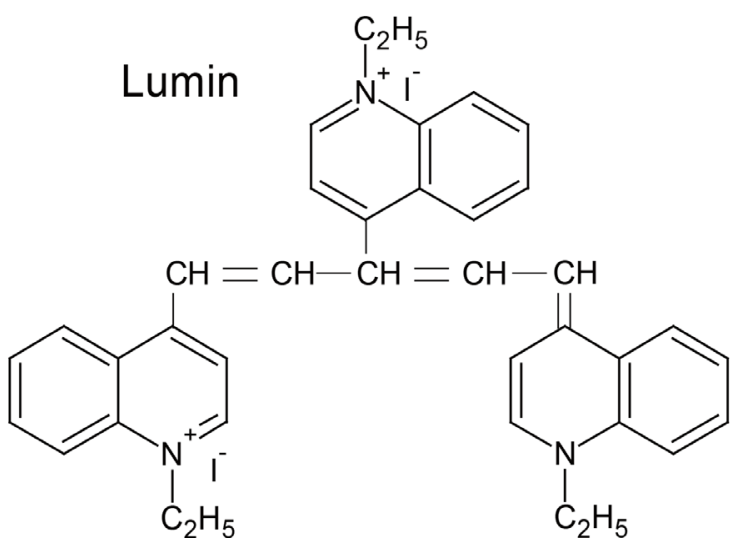

Figure 1: Structures of chemical compounds. 
$\mathrm{Ca}^{2+}$ entry in mTRPV2-expressing HEK293 cells (Figure 3A) and were more potent than tranilast and SKF96365 $\left(\mathrm{IC}_{50}<2 \mu \mathrm{M}\right.$ for $\mathrm{A} 3 ; \mathrm{IC}_{50}<10 \mu \mathrm{M}$ for A48 and A63; IC approximately $4 \mu \mathrm{M}$ for B6) (Figure 3B). Other tested chemical compounds, including A65 and B33 (data not shown), had negligible effects on the 2-APB-induced increase in $\left[\mathrm{Ca}^{2+}\right]_{\mathrm{i}}$ (Figure $\left.3 \mathrm{~A}\right)$.
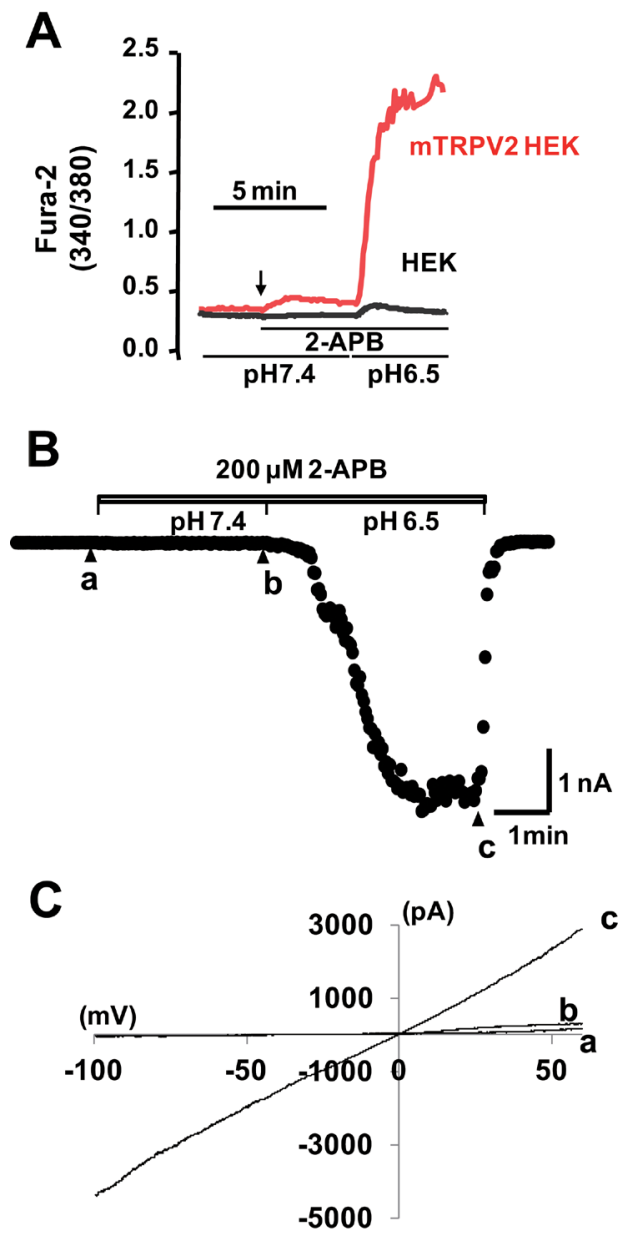

\section{Specificity of TRPV2 inhibitors}

Unlike mTRPV2, human TRPV2 (hTRPV2) is unresponsive to 2-APB [21]. Therefore, to determine whether the identified chemical compounds inhibit other human TRP family members, the increase in $\left[\mathrm{Ca}^{2+}\right]_{\mathrm{i}}$ induced by a high concentration $(5 \mathrm{mM})$ of extracellular
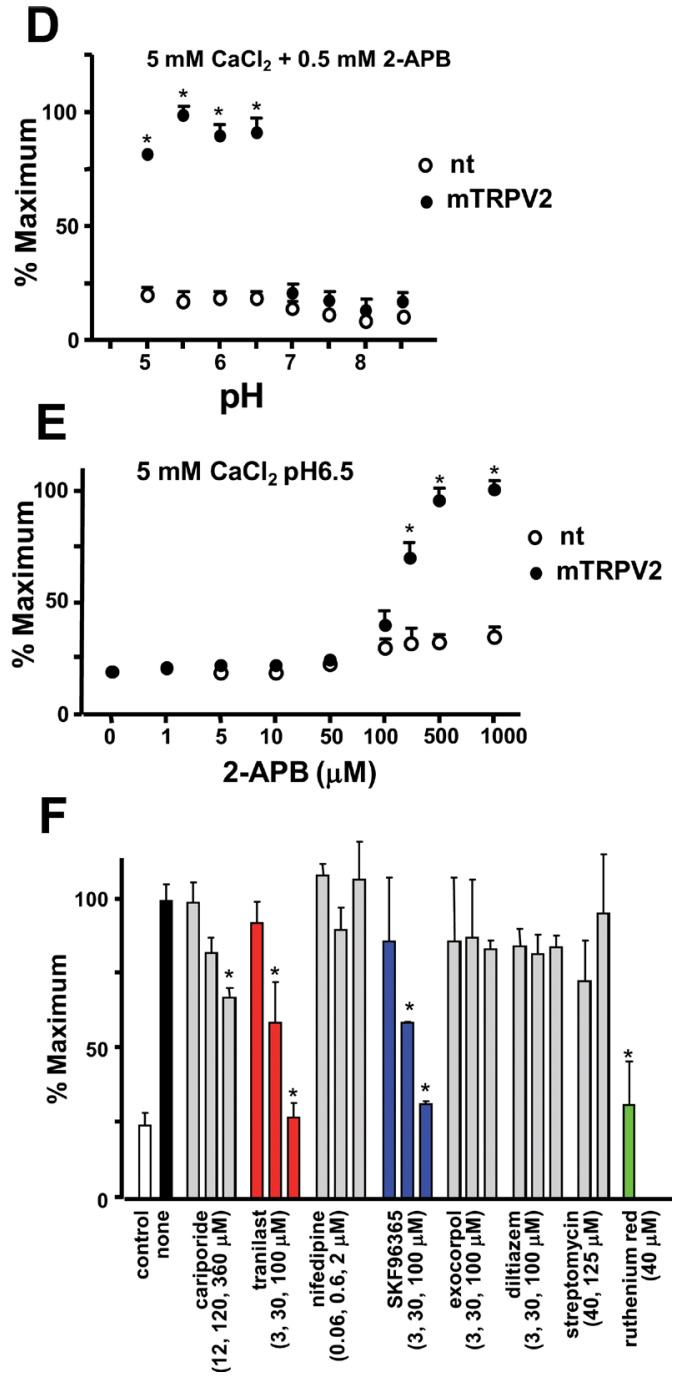

Figure 2: Effects of extracellular $\mathrm{pH}$ and 2-APB on $\mathrm{Ca}^{2+}$ response and TRPV2 channel activity in $\mathrm{HEK} 293$ cells expressing TRPV2. (A) Non-transfected (HEK) or mTRPV2-transfected HEK293 cells were loaded with $4 \mu \mathrm{M}$ fura2-AM and maintained in BSS containing low $\mathrm{CaCl}_{2}(0.5 \mathrm{mM})$ at $\mathrm{pH}$ 7.4. Cells were stimulated with medium $(\mathrm{pH} 7.4)$ containing $\mathrm{CaCl}_{2}(5 \mathrm{mM})$ and 2-APB $(500 \mu \mathrm{M})$ (arrow), followed by exposure to low $\mathrm{pH}(6.5)$ medium containing $\mathrm{CaCl}_{2}$ and 2-APB. (B) Traces of currents elicited by the ramp protocol. The mTRPV2 currents were recorded with the holding potential at $-60 \mathrm{mV}$. The patch clamped cells were perfused with medium (pH 7.4) containing $200 \mu \mathrm{M}$ 2-APB and then switched to the low $\mathrm{pH}(6.5)$ medium. The current values at $-100 \mathrm{mV}$ with an every2-second ramp protocol were plotted. (C) Current-voltage relationship. The time points for the traces shown as a, b, and c are shown in (B). (D) Extracellular $\mathrm{pH}$-dependence of the $\mathrm{Ca}^{2+}$ response measured by the fluorescence microplate reader. Cells were initially incubated in BSS containing low $\mathrm{CaCl}_{2}(0.5 \mathrm{mM})$ at $\mathrm{pH} 7.4$ and then switched to BSS containing high $\mathrm{CaCl}_{2}(5 \mathrm{mM})$ and $2-\mathrm{APB}(0.5 \mathrm{mM})$ at the indicated $\mathrm{pH}$ values. Fura-2-AM fluorescence was measured at excitation wavelengths of 340 and $380 \mathrm{~nm}$. The fluorescence ratio measured at $340 / 380 \mathrm{~nm}$ was normalized by the maximal value and plotted. The data represent mean $\pm \mathrm{SD}$ values $\left(n=5 /\right.$ group); ${ }^{*} P<0.05$. (E) Dependence of the $\mathrm{Ca}^{2+}$ response on 2-APB concentration. The medium was switched to BSS at an acidic $\mathrm{pH}(6.5)$ containing high $\mathrm{CaCl}{ }_{2}$ and various concentrations of 2 -APB. The data represent mean $\pm \mathrm{SD}$ values $(n=5 /$ group $) ;{ }^{*} P<0.05$. (F) Cells were stimulated with 2 -APB $(0.3 \mathrm{mM})$ and $\mathrm{CaCl}_{2}(5 \mathrm{mM})$ at $\mathrm{pH} 6.5$ in the absence or presence of each compound at the indicated concentrations. The fluorescence ratio at $340 / 380 \mathrm{~nm}$ was normalized by the value measured with 2-APB alone. Open bar, no 2-APB (control). The data represent mean \pm SD values $(n=5 /$ group $) ;{ }^{*} P<0.05$. 
$\mathrm{CaCl}_{2}$ was measured in $\mathrm{CHO}$ cells expressing hTRPV2 using a fluorescence ratio monitoring system. In this experiment, we used CHO cells instead of HEK293 cells, because the $\mathrm{Ca}^{2+}$ response induced by high (extracellular) $\mathrm{Ca}^{2+}$ is detected relatively easily in $\mathrm{CHO}$ cells. $\mathrm{Ca}^{2+}$ influx in response to $\mathrm{CaCl}_{2}$ exposure was observed in $\mathrm{CHO}$ cells expressing either mTRPV2 or hTRPV2 [17]. The observed $\mathrm{Ca}^{2+}$ influx in response to $\mathrm{CaCl}_{2}$ exposure was markedly inhibited by A3, A48, and A63, but not by B6 (Figure 4A) or B33 (data not shown). The differential effects of B6 on mTRPV2 and hTRPV2 may be explained by subtle, species-specific variations in the primary structure of the channel. The increase in $\left[\mathrm{Ca}^{2+}\right]_{\mathrm{i}}$ induced by 2-APB was also observed in cells expressing hTRPV1 and was comparable to that induced by capsaicin, a specific TRPV1 agonist. However, in contrast to TRPV2, the increase in $\left[\mathrm{Ca}^{2+}\right]_{\mathrm{i}}$ via TRPV1 was unaffected by exposure to A3, A48, A63, or B6 (Figure 4B). The effects of A3, A48, A63, and $\mathrm{B} 6$ on store-operated increases in $\mathrm{Ca}^{2+}$ in cells expressing hTRPC1 were examined after the $\mathrm{Ca}^{2+}$ store was depleted with thapsigargin in $\mathrm{Ca}^{2+}$-free medium and the cells were exposed to high extracellular $\mathrm{Ca}^{2+}$ to induce an increase in

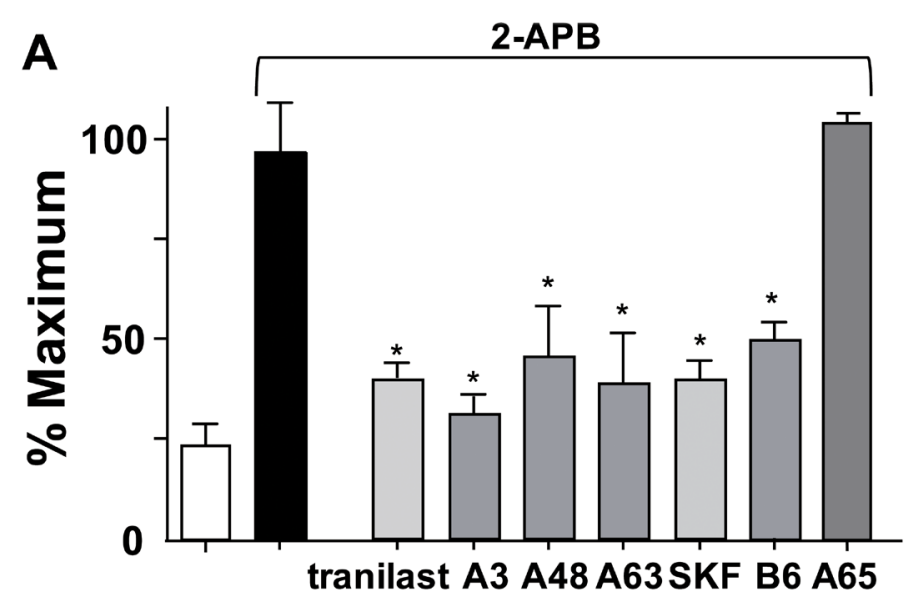

B
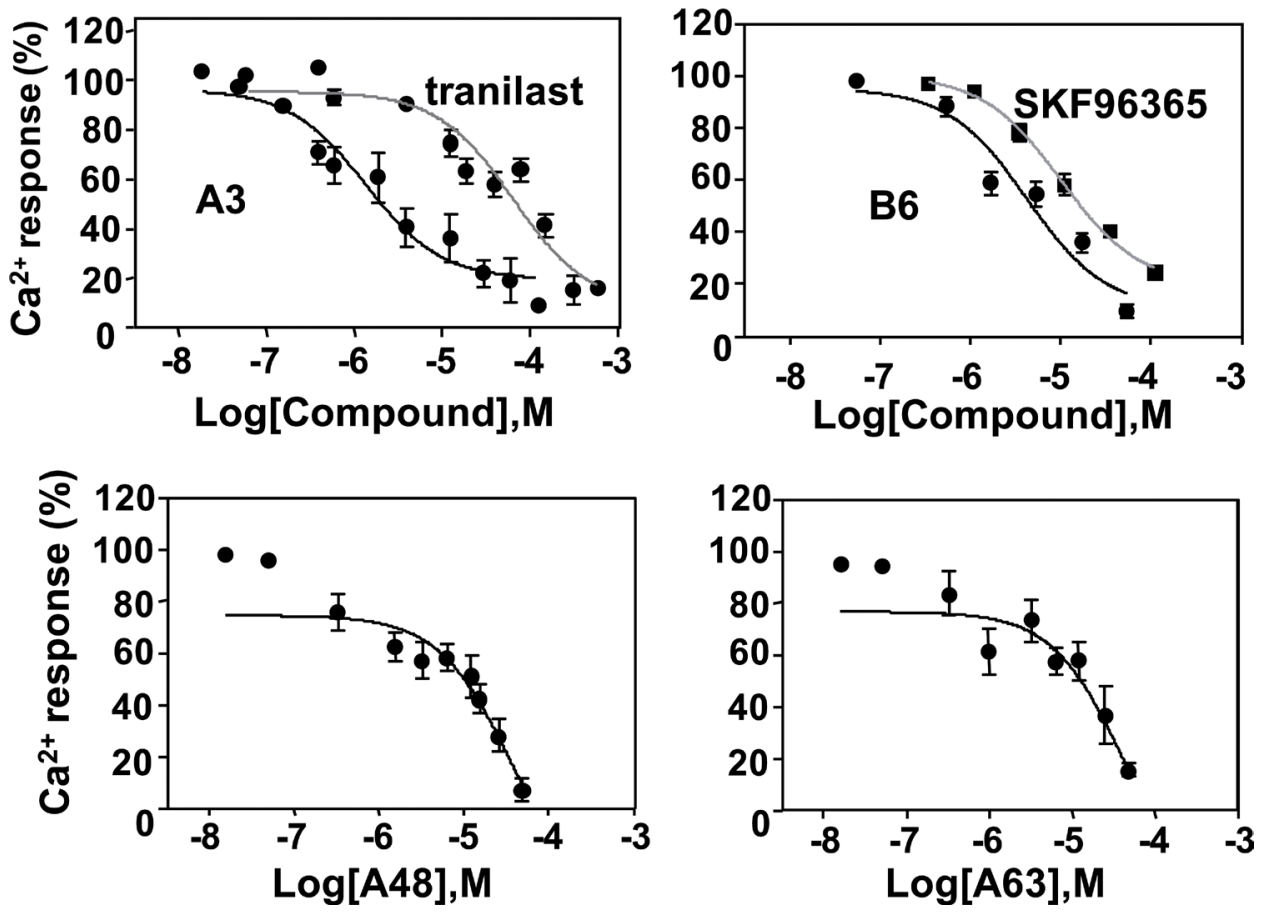

Figure 3: Effects of inhibitor compounds on 2-APB-induced $\mathrm{Ca}^{2+}$ increase in HEK293 cells expressing mTRPV2. (A) Cells cultured in 96 well plates were stimulated with 2-APB $(0.3 \mathrm{mM})$ and $\mathrm{CaCl}_{2}(5 \mathrm{mM})$ at $\mathrm{pH} 6.5$ in the absence (solid bar) or presence of each candidate inhibitor $(15 \mu \mathrm{M})$, tranilast $(100 \mu \mathrm{M})$, or SKF96365 $(100 \mu \mathrm{M})$. Open bar, no 2-APB or inhibitor. Data are shown as mean $\pm \mathrm{SD}(n=5) .{ }^{*} P<0.05$. (B) Concentration-dependence of inhibition of the 2-APB-induced $\mathrm{Ca}^{2+}$ response. The 2-APB-induced increase in fluorescence at $340 / 380 \mathrm{~nm}$ was normalised to that measured in the absence of the inhibitors. Data are shown as mean $\pm \operatorname{SD}(n=5)$. 
A
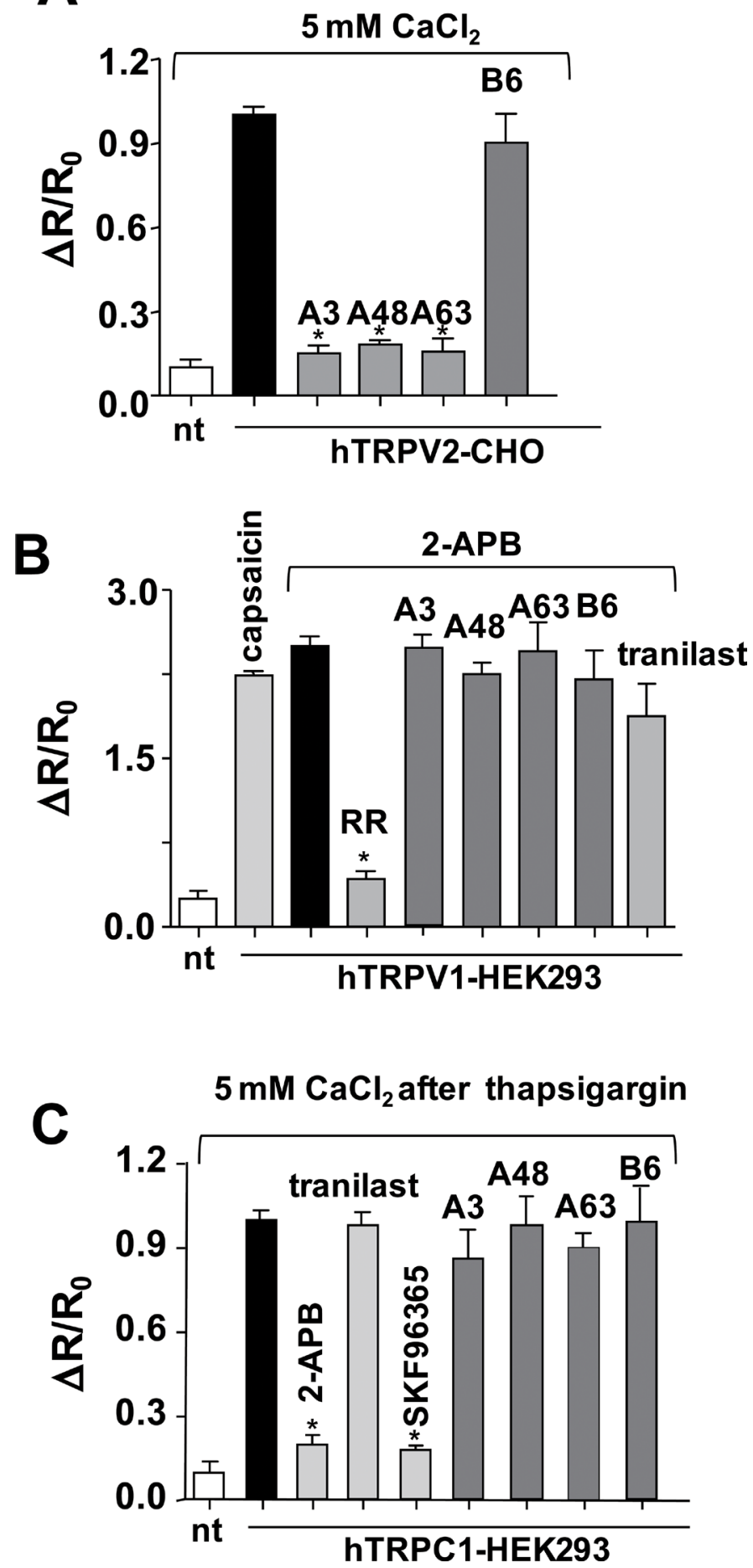

Figure 4: Effects of inhibitor compounds on the $\mathrm{Ca}^{2+}$ response of cells expressing hTRPV1, hTRPV2, or hTRPC1. (A) Effect of compounds on $\mathrm{CaCl}_{2}(5 \mathrm{mM})$-induced peak fluorescence ratio in non-transfected (nt) or hTRPV2-transfected CHO cells. The extracellular $\mathrm{Ca}^{2+}$-dependent increase in the ratio of fura- 2 fluorescence intensity at $340 / 380 \mathrm{~nm}(\Delta \mathrm{R}, 2$ min after addition of chemicals) was plotted as $\Delta \mathrm{R} / \mathrm{R}_{0}$ after normalising to the initial fluorescence ratio $\left(\mathrm{R}_{0}\right)$. Concentration of $\mathrm{A} 3, \mathrm{~A} 48, \mathrm{~A} 63$, and $\mathrm{B} 6$ : $15 \mu \mathrm{M}$. Solid bar, no inhibitor. (B) Effect of compounds on 2-APB $(1 \mathrm{mM})$ /high extracellular $\mathrm{CaCl}_{2}$-induced peak fluorescence ratio in nt or hTRPV1-transfected HEK293 cells. The 2-APB/high extracellular $\mathrm{Ca}^{2+}$-dependent increase $(\triangle \mathrm{R})$ in the fluorescence intensity ratio was measured 2 min after addition of 2-APB. Concentrations: capsaicin and tranilast, $100 \mu \mathrm{M}$; ruthenium red (RR), $40 \mu \mathrm{M}$; A3, A48, A63, and B6, $15 \mu \mathrm{M}$. (C) Effect of compounds on store-operated $\mathrm{Ca}^{2+}$ entry in nt or hTRPC1-transfected HEK293 cells. Cells were treated with the endoplasmic reticulum $\mathrm{Ca}^{2+}$ pump inhibitor thapsigargin and exposed to $\mathrm{CaCl}_{2}$ and the indicated compounds. $\Delta \mathrm{R}$ was measured 2 min after the addition of $\mathrm{CaCl}_{2}$. Concentrations: 2-APB, $10 \mu \mathrm{M}$; tranilast and SKF96365, $100 \mu \mathrm{M}$; A3, A48, A63, and B6, $15 \mu \mathrm{M}$. Data are shown as mean \pm SD $(n=5)$. 
$\left[\mathrm{Ca}^{2+}\right]_{\mathrm{i}} \cdot 2$-APB inhibited the store-operated $\mathrm{Ca}^{2+}$ increase in $\left[\mathrm{Ca}^{2+}\right]_{i}$ in these cells, consistent with previous reports that 2-APB is a potent non-specific inhibitor of TRPC family members [24]. While SKF96365 strongly inhibited this response, neither A3, A48, A63, nor B6 had any effect (Figure 4C). These results suggest that A3, A48, and A63 inhibit TRPV2, but not TRPV1 or TRPC1.

\section{Protective effects of TRPV2 candidate inhibitors against abnormal $\mathrm{Ca}^{2+}$ handling and $\mathrm{CK}$ release in dystrophic myocytes from dystrophic hamsters (J2N-k)}

Perfusion with high extracellular $\mathrm{Ca}^{2+}(5 \mathrm{mM})$ raised $\left[\mathrm{Ca}^{2+}\right]$ in dystrophic myocytes from $\mathrm{J} 2 \mathrm{~N}-\mathrm{k}$, but not in normal myocytes from wild-type $\mathrm{J} 2 \mathrm{~N}-\mathrm{n}$ hamsters (Figure 5A), consistent with previous observations [17]. The extracellular $\mathrm{Ca}^{2+}$-induced increase in $\left[\mathrm{Ca}^{2+}\right]_{\mathrm{i}}$ in $\mathrm{J} 2 \mathrm{~N}-\mathrm{k}$ myocytes was almost completely abolished by A48 (Figure 5B). A 2-APBinduced increase in $\left[\mathrm{Ca}^{2+}\right]_{\mathrm{i}}$ was detected only in $\mathrm{J} 2 \mathrm{~N}-\mathrm{k}$ myocytes (Figure 5C) and was abolished by A48 (Figure 5D). All TRPV2 inhibitors effectively inhibited high (extracellular) $\mathrm{Ca}^{2+}$ - and 2-APB-induced increases in $\left[\mathrm{Ca}^{2+}\right]_{\mathrm{i}}$ in $\mathrm{J} 2 \mathrm{~N}-\mathrm{k}$ myocytes (Figure 5E, 5F). These results suggest that $\mathrm{Ca}^{2+}$ influx through TRPV2 is a major contributor to abnormal $\mathrm{Ca}^{2+}$ handling observed in $\mathrm{J} 2 \mathrm{~N}-\mathrm{k}$ myocytes. In addition, these results demonstrate that at least 3 (A3, A48, and A63) of the newly identified TRPV2 inhibitors effectively target hamster, mouse, and human TRPV2 isoforms.

To assess the effects of the newly identified TRPV2 inhibitors on mechanical stretch-induced muscle degeneration, J2N-k myocytes were treated with a test agent for $30 \mathrm{~min}$, after which cyclic stretch (20\% elongation) was applied for $1 \mathrm{~h}$. CK release was measured as an indicator of muscle damage. Treatment of myocytes with A3, A48, or A63 (30 $\mu \mathrm{M})$, as well as tranilast $(500 \mu \mathrm{M})$, reduced stretch-induced CK release from $\mathrm{J} 2 \mathrm{~N}-\mathrm{k}$ myocytes by up to $70 \%$ (Figure $5 \mathrm{G}$ ).

\section{Protective effects of TRPV2 inhibitor candidates on cardiomyopathy in vivo}

To test the efficacy of the newly identified TRPV2 inhibitors in vivo, they were administered for 3 weeks to 9-week-old hamsters showing decreased cardiac function, after which echocardiography was performed (Figure 6A). J2N-k hamsters showed left ventricular cavity dilation (Figure 6A). In contrast to small effect on left ventricular end-diastolic dimension (LVDd) (Figure 6B), tranilast, A3, A48, A63, and B6 prevented the increase in left ventricular end-systolic dimension (LVDs) (Figure 6C) and decrease in FS (Figure 6D), while A65 (a negative compound identified by screening) was ineffective. Tranilast, A3, A48, A63, and B6, but not A65, also reduced the serum level of cTN-I, a marker for heart cell damage (Figure 6E). Consistent with the echocardiography results, treatment with A3 prevented fibrosis, as revealed by
Masson's trichrome staining (Figure 7A). As summarized in Figure 7B, A3, A48, and tranilast prevented fibrosis.

\section{Identification of lumin as a TRPV2 inhibitor and its protective effect on cardiomyopathy}

In parallel with drug screening based on structural similarity with tranilast or SKF96365, we attempted to identify TRPV2 inhibitors by screening various offpatent drugs. A screening of photosensitive dyes yielded lumin [25] as a candidate TRPV2 inhibitor. Lumin inhibited 2-APB-induced $\mathrm{Ca}^{2+}$ influx through mTRPV2 in HEK293 cells at a concentration 10-fold lower than the concentration of tranilast required to produce a similar effect (compare Figures 8A and 3B). In addition, lumin inhibited high (extracellular) $\mathrm{Ca}^{2+}$-induced or 2-APBinduced increase in $\left[\mathrm{Ca}^{2+}\right]_{\mathrm{i}}$ in dystrophic myotubes from $\mathrm{J} 2 \mathrm{~N}-\mathrm{k}$ hamsters (Figure $5 \mathrm{E}$ and $5 \mathrm{~F}$ ). Lumin $(15 \mu \mathrm{M})$ also reduced the 2-APB-induced current (Figure 8B) at all tested voltages (Figure $8 \mathrm{C}$ ), the $\mathrm{IC}_{50}(5 \mu \mathrm{M})$ of lumin for the ion current was very similar to the $\mathrm{IC}_{50}$ for the $\mathrm{Ca}^{2+}$ response $(<5 \mu \mathrm{M})$ under our experimental conditions. Lumin $(15 \mu \mathrm{M})$ did not inhibit the L-type current (Figure $8 \mathrm{E}): 96.6 \pm 8.7 \%(n=3)$ of control at $15 \mu \mathrm{M}$ lumin. Lumin did not affect the increase in $\left[\mathrm{Ca}^{2+}\right]_{\mathrm{i}}$ via TRPV1 or TRPC1 (unpublished observation). When lumin was administered to 9-week-old J2N-k hamsters for 3 weeks, the decrease in wall thickness was partially prevented, fibrotic area was reduced $(10 \mathrm{mg} / \mathrm{kg}$ dose, Figure 9A-9C), and cardiac dysfunction (increased LVDs, reduced ejection fraction, and decreased fractional shortening) was prevented (Figure 9D).

\section{DISCUSSION}

An assay system developed to measure TRPV2 activation by high throughput screening was used to identify several TRPV2 inhibitors that could be used to treat patients with muscle disorders caused by abnormal $\mathrm{Ca}^{2+}$ handling. Besides 2-APB, Lysophospholipids [26], probenecid [27], and cannabidiol [28] have been identified as agents that induce increased $\left[\mathrm{Ca}^{2+}\right]_{\mathrm{i}}$ in HEK293 cells expressing TRPV2 [26-28]. Koch [29] and Rubinstein [30] identified probenecid as a potent TRPV2 agonist in cardiomyocytes. We observed a small $\left[\mathrm{Ca}^{2+}\right]_{\mathrm{i}}$ increase induced by these agonists in TRPV2-expressing HEK293 cells. However, the $\mathrm{Ca}^{2+}$ response was too small for use as a high-throughput screening procedure for the inhibitors. We found that treating cells with 2-APB in a weak acidic medium ( $\mathrm{pH}$ 6.5) was a reasonably effective way of measuring increases in $\left[\mathrm{Ca}^{2+}\right]_{\mathrm{i}}$ mediated by TRPV2. Exposure to weak acidic medium in the presence of 2-APB also dramatically activated the TRPV2 current measured under voltage-clamped conditions using the whole cell patch clamp technique. As previously reported by Chung [31], 2-APB had only a small effect on mTRPV2 under 
neutral conditions (Figure 2). TRPV1, a TRPV family member sharing $46 \%$ identity in the primary amino acid sequence with TRPV2 [32], is directly activated by low external $\mathrm{pH}$. The evidence presented here shows that TRPV2 can be activated by $\mathrm{H}^{+}$, although direct activation of TRPV2 by low $\mathrm{pH}$ has not yet been reported. The $\mathrm{pK}_{\mathrm{a}}$ of 2-APB is approximately 10 , which means that its amine group is protonated at physiological or lower $\mathrm{pH}$, giving the molecule a net positive charge. Thus, the present results suggest that the $\mathrm{H}^{+}$-sensitivity of TRPV2 is due to the existence of a proton-responsive region within the TRPV2 molecule and not to the effect of protonation of 2-APB.

The screening identified several candidate TRPV2 blockers. A3, A48, and A63 were derived from tranilast and had inhibitory potency 2-10-fold higher than that of tranilast (A3 > A48 >A63). A3, A48, and A63 had similar effects on mTRPV2 and hTRPV2. In contrast, B6 was the only compound identified by the screening that was based on SKF96365. Although the inhibitory effect of B6 against mouse TRPV2 was slightly greater than that of SKF96365 (Figure 3B), it had no effect on cells expressing hTRPV2 (Figure 4A). Thus, like 2-APB, the effectiveness of B6 on TRPV2 was speciesspecific, suggesting that the mechanism of inhibition by B6 may be different from that of tranilast derivatives. Ruthenium red is known as a broad inhibitor of many $\mathrm{Ca}^{2+}$-permeable ion channels. In addition, the potassium channel blockers tetraethylammonium, 4-amino-pyridine, and 1-(2-(trifluoromethyl)phenyl)imidazole inhibit TRPV2 activation [21]. However, effective doses of these agents are much higher $(100-1000 \mu \mathrm{M})$ than those of the candidate inhibitors reported here.

In addition to $\mathrm{Ca}^{2+}$ influx via TRPV2, we examined the effects of chemical compounds on TRPV2 channel activity under voltage clamp conditions. We found that lumin effectively blocked TRPV2 channel activity (Figure 8B-8D). However, other inhibitors (A3, A48, A63, and B6) only slightly inhibited TRPV2 channel activity (up to $25 \%$ inhibition at $15 \sim 30 \mu \mathrm{M}$ ) (data not shown). Thus, the weak effects of these drugs on channel activity were different from their relatively strong inhibitory effects on the $\mathrm{Ca}^{2+}$ response $\left(\mathrm{IC}_{50}<2 \sim 10 \mu \mathrm{M}\right)$. At present, we do not know the reason why the procedures used to detect TRPV2
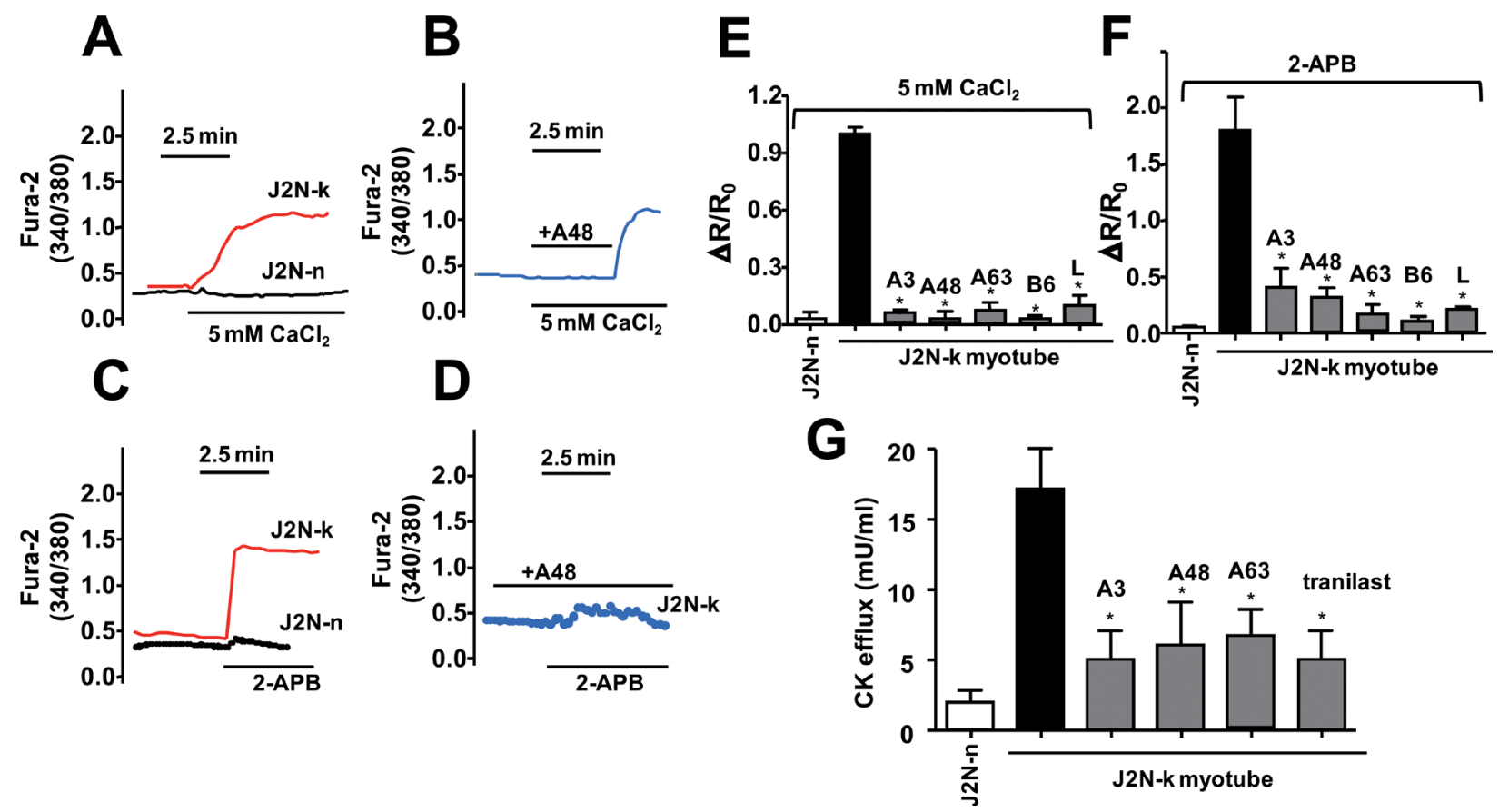

Figure 5: Effect of inhibitor compounds on the $\mathrm{Ca}^{2+}$ response in myocytes from hamster skeletal muscles. (A) Typical traces from ratiometric scanning of fura-2-AM fluorescence in myocytes prepared from wild-type (J2N-n) or dystrophic (J2N-k) hamsters. Myocytes loaded with fura-2-AM were incubated in BSS containing a low concentration of $\mathrm{CaCl}(0.5 \mathrm{mM})$, then exposed to a high concentration of $\mathrm{CaCl}_{2}(5 \mathrm{mM})$. The data represent mean values $\left(n=5-10\right.$ /group). (B) Effect of A48 on the Ca ${ }^{2+}$ response. Myocytes from J2N-k hamsters were exposed to high $\mathrm{Ca}^{2+}$ with $\mathrm{A} 48(15 \mu \mathrm{M})$ for 3 min, after which A48 was removed from the medium. (C) Myocytes loaded with fura-2-AM were incubated in BSS with a low concentration of $\mathrm{CaCl}_{2}(0.5 \mathrm{mM})$, after which the medium was replaced with BSS containing a high concentration of $\mathrm{CaCl}_{2}(5 \mathrm{mM})$ and 2-APB $(0.5 \mathrm{mM})$ at $\mathrm{pH} 6.5$. The data represent mean values ( $n=5-10$ /group). (D) An experiment similar to that shown in (C) was performed in the presence of A48. $(\mathbf{E}, \mathbf{F})$ Effects of compounds on the $\mathrm{CaCl}_{2}$ - and 2-APB-induced increases in the relative fura-2 fluorescence ratio $\left(\Delta \mathrm{R} / \mathrm{R}_{0}\right)$, which was calculated from the fluorescence intensity at $340 / 380 \mathrm{~nm}$ before and after exposure to $\mathrm{CaCl}_{2}$ or 2-APB. The concentration of each compound was $15 \mu \mathrm{M}$ (L, lumin). Data are shown as mean $\pm \mathrm{SD}(n=5) .{ }^{*} P<0.05$. (G) Stretch-induced CK release from myocytes into the medium in the absence or presence of each drug $(15 \mu \mathrm{M})$. Data are shown as mean $\pm \mathrm{SD}(n=5) .{ }^{*} P<0.05$. 
activity gave different results. One likely possibility is that lipophilic agonist 2-APB may modulate the membrane integrity or interaction of TRPV2 with membrane lipids more strongly in a single cell experimental setting (such as patch clamp) in comparison with a cultured cell monolayer, which may offset the inhibition by other lipophilic chemical compounds. Indeed, similar to our observation, the effectiveness of other TRPV2 blockers was much reduced when high concentrations of 2-APB were used [21]. Furthermore, while tranilast $(100 \mu \mathrm{M})$ did not inhibit channel activity when $200 \mu \mathrm{M} 2$-APB was used (data not shown), it blocked the pressure-induced inward current in TRPV2-transfected HEK293 cells [33].

We reported that TRPV2 accumulated in the sarcolemma of heart muscle cells and skeletal muscles cells in patients with DCM and muscular dystrophy, respectively $[16,19]$. In addition, it has been reported that TRPV2 is involved in myotubes from patients with Duchenne muscular dystrophy [34]. Thus, specific inhibitors of TRPV2 could potentially be effective treatments for patients with various degenerative and hereditary diseases affecting muscles. An interesting
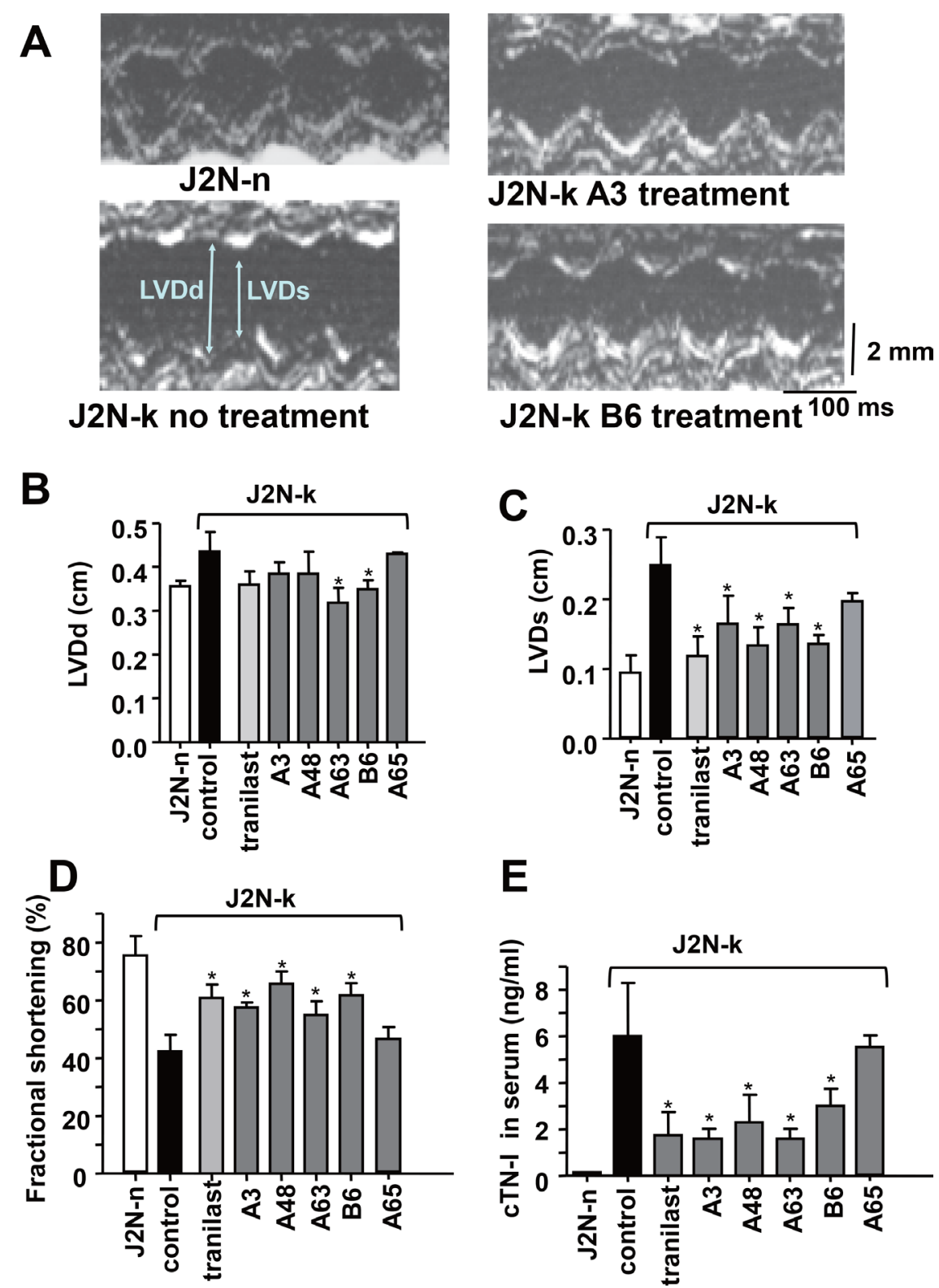

Figure 6: Protective effects of TRPV2 inhibitors against cardiac dysfunction in J2N-k hamsters. (A) Representative echocardiogram from each group showing left ventricular end diastolic and systolic dimensions (LVDd and LVDs, respectively) in wildtype (J2N-n) and cardiomyopathic (J2N-k) hamsters with or without inhibitor treatment. (B-D) Effect of inhibitors on LVDd, LVDs, fractional shortening (FS), and (E) cTN-I level in the serum. Solid black bar, no inhibitor. Data are shown as $\operatorname{mean} \pm \operatorname{SD}(n=4)$. ${ }^{*} P<0.05$ vs. water in J2N-k hamsters. 
aspect of TRPV2 as a therapeutic target is that it can be blocked using 2 fundamentally different strategies: by inhibiting sarcolemmal accumulation or channel activity. With regard to inhibition of sarcolemmal accumulation, we previously reported that reduction of sarcolemmal TRPV2 by overexpression of its amino terminal domain prevented cardiac dysfunction and DCM progression in animal models, while enhancing survival [19]. In addition, the present study provides evidence for the therapeutic potential of TRPV2 channel inhibition. A3 A48, A63, $\mathrm{B} 6$, and lumin blocked the progression of DCM in J2N-k hamsters, likely due to inhibition of $\mathrm{Ca}^{2+}$ influx through TRPV2; thus, TRPV2 may be an upstream factor in abnormal $\mathrm{Ca}^{2+}$ handling. Recently, genetic ablation of TRPV2 was reported to reduce heart performance [30] and result in abnormal cardiac structure and function [35]. These studies suggest that TRPV2 plays an essential role in maintaining normal cardiac structure and function. However, while TRPV2 inhibitors prevented cardiac dysfunction in DCM hamsters, they had no obvious detrimental effects on isolated normal cardiomyocytes or healthy control animals (Y. Iwata, et al., unpublished observation). Thus, TRPV2 inhibitors would not be expected to exert detrimental effects during limited administration periods. Further studies are required to assess the therapeutic uses of TRPV2 inhibitors.

In this study, we identified several TRPV2 inhibitors. Lumin has antioxidant, antitumor, and immunopotentiating effects [25, 36, 37]. Here, lumin was found to have a protective effect against DCM. Lumin has clinical potential because it is commercially available as an immunostimulant and is apparently without side effects. Tranilast is also available to patients as an anti-inflammatory and immunomodulatory compound and could also have clinical potential as a treatment for patients with DCM. To this end, novel inhibitors derived from tranilast may also have high therapeutic potential owing to their relatively low effective doses.
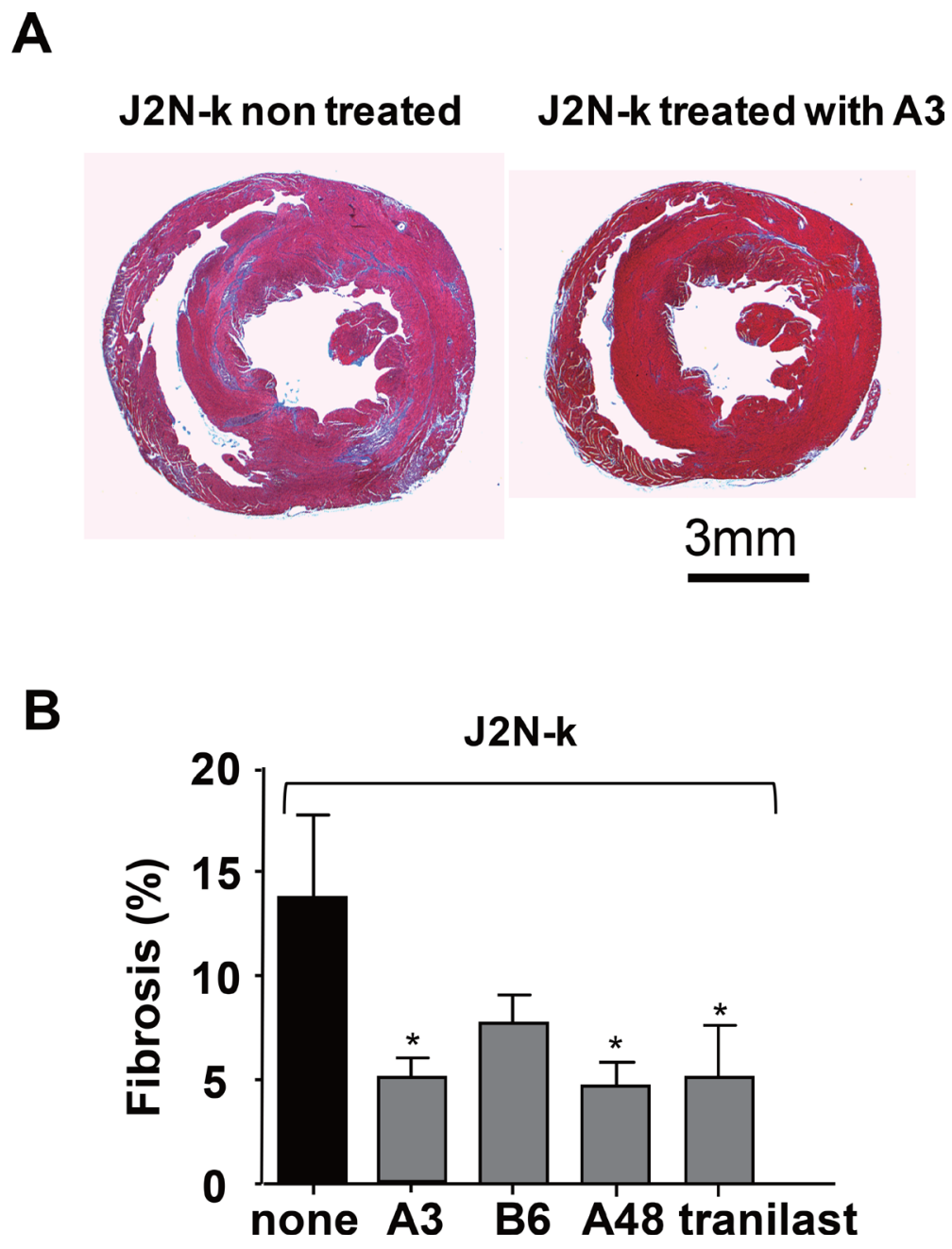

Figure 7: Suppression of fibrosis in the hearts of cardiomyopathic hamsters by TRPV2 inhibitors. (A) Representative Masson's trichrome staining of transverse heart sections from J2N-k hamsters with or without A3 treatment. (B) Quantitative analysis of fibrotic area with or without drug treatment. Data are shown as mean $\pm \mathrm{SD}(n=3-5 /$ group $) .{ }^{*} P<0.05$. 


\section{MATERIALS AND METHODS}

\section{Animal experiments}

Male $\delta$-SG-deficient cardiomyopathic J2N-k and age-matched wild-type J2N-n hamsters (9 weeks old) were purchased from Japan SLC, Inc. (Shizuoka, Japan). Tranilast was ingested mixed with feed $(300 \mathrm{mg} / \mathrm{kg} /$ day $)$ as described previously, whereas other drugs (Figure 1) were administered orally in the drinking water at doses of $30 \mathrm{mg} / \mathrm{kg}$ (except lumin) per day for 3 weeks. In case of lumin, we first performed dose-dependent experiment at dose of 1,10 and $100 \mathrm{mg} / \mathrm{kg}$ per day for 3 weeks, in order to determine the effective dose. And then we repeated experiments at an effective dose $(10 \mathrm{mg} / \mathrm{kg})$ for 3 weeks. After drug treatment, serum cardiac troponin (cTN)-I was measured and echocardiography analysis was performed. Histochemistry of cardiac muscles was performed as previously described [38]. All animal experiments were performed according to the Guidelines for Animal Experimentation of the National Cerebral and Cardiovascular Center Research Institute.

\section{Histology}

Ventricles were fixed in phosphate-buffered saline containing $10 \%$ formalin and embedded in paraffin. Serial sections were cut at a thickness of $5 \mu \mathrm{m}$ and stained with
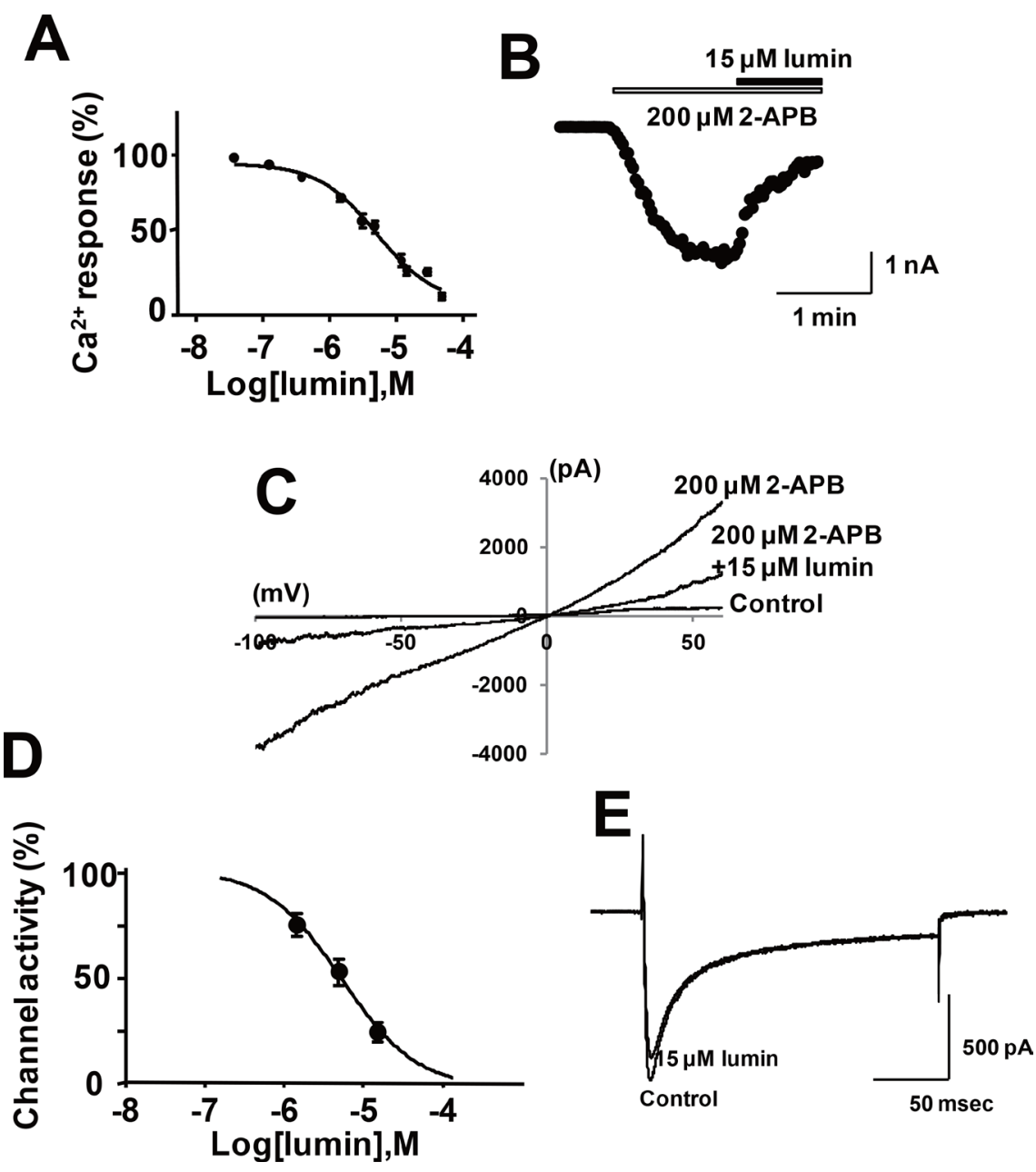

Figure 8: Effect of lumin on the $\mathrm{Ca}^{2+}$ response and channel activity in HEK293 cells expressing mTRPV2. (A) Inhibition of the 2-APB-induced increase in $\left[\mathrm{Ca}^{2+}\right]_{\mathrm{i}}$ in HEK293 cells expressing mTRPV2 by lumin. Cells were loaded with fura-2-AM and stimulated with 2-APB $(0.3 \mathrm{mM})$ in the absence or presence of the indicated concentrations of lumin. The fluorescence ratio was measured by a microplate reader and normalized by the maximal value. Data are shown as mean $\pm \operatorname{SD}(n=5)$. (B) Lumin blocked the mTRPV2 channel. The current values at $-100 \mathrm{mV}$ measured by an every-2-second ramp protocol were plotted. After the current activated by $200 \mu \mathrm{M} 2$-APB at $\mathrm{pH} 6.5$ became stable, a mixture of $15 \mu \mathrm{M}$ lumin and 2-APB was applied to the cells. (C) Effect of lumin on the current-voltage relationship of 2-APB-evoked current. (D) Concentration-dependence of lumin for the inhibition of mTRPV2 current. Data are shown as mean $\pm \mathrm{SD}$ $(n=3-5)(\mathbf{E})$ Effect of lumin $(15 \mu \mathrm{M})$ on L-type $\mathrm{Ca}^{2+}$ channel activity. The current waveforms of the control cells and the cells 11 minutes after application of $15 \mu \mathrm{M}$ lumin were superimposed. The L-type $\mathrm{Ca}^{2+}$ channel currents were elicited by depolarizing pulses of $0 \mathrm{mV}$ for 200 milliseconds from $-80 \mathrm{mV}$. 
Masson's trichrome stain for morphological analysis. Sections were viewed under a BX41 light microscope (Olympus, Tokyo, Japan). Images were acquired with an FX380 digital camera (Olympus) and analysed using an FLVFS-LS imaging system (Flovel, Tokyo, Japan).

Fibrosis was assessed by measuring Masson's trichrome-positive areas. Briefly, colour images were converted to binary form by setting the threshold value so as to detect only blue-stained fibrotic areas, which were summed and reported as a percentage of the total.

\section{Echocardiography}

Cardiac function was evaluated by echocardiography using a Sonos5500 ultrasound system (Hewlett-Packard,
Palo Alto, CA, USA) with a 12-MHz transducer and M-mode imaging. The animals were sedated with tribromoethanol $(350 \mathrm{mg} / \mathrm{kg}$ by intraperitoneal injection) during the process.

\section{Reagents}

Cariporide was a gift from Sanofi-Aventis (Bridgewater, NJ, USA). Poloxamer 188 (Exocorpol) was purchased from Midori Juji Co., Ltd. (Osaka, Japan). Nifedipine, streptomycin, 2-APB, 2-[(4-methoxyphenyl) carbonylamino]-3-methylbenzoic acid (A48) (S770000), and diltiazem were purchased from Sigma-Aldrich (St. Louis, MO, USA). Tranilast was obtained from Kissei Pharmaceutical (Matsumoto City, Japan). SKF96365 and ionomycin were obtained from Calbiochem (La
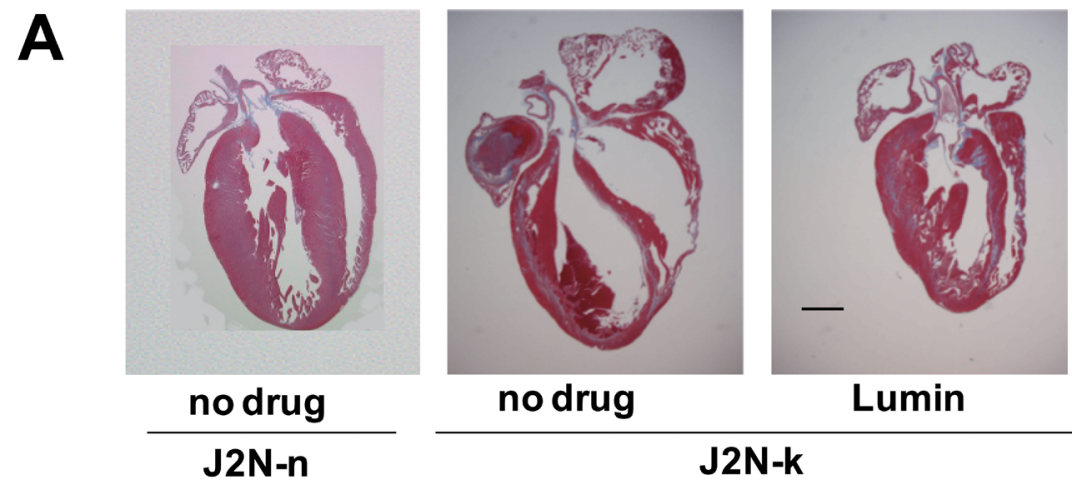

no drug

Lumin

B
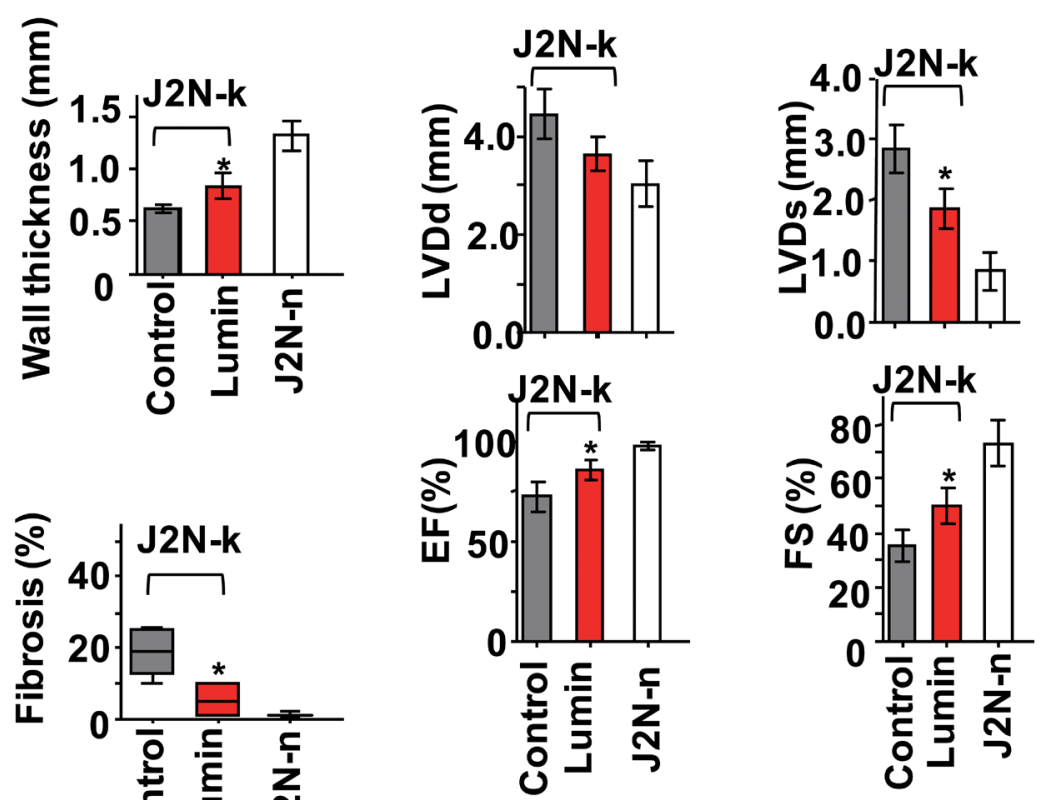

Figure 9: Protective effect of lumin against cardiomyopathy. (A) Representable Masson's trichrome staining of cardiac sections from wild-type J2N-n and cardiomyopathic J2N-k hamsters administered no compound (control) or lumin (10 mg/kg). Scale bar: $1 \mathrm{~mm}$. (B and C) Quantitative analysis of septal wall thickness (B) and fibrotic area (C). (D) Effect of lumin (10 mg/kg) administration on echocardiographic parameters. Grey bar, no compound (control); EF, ejection fraction; FS, fractional shortening. Data are shown as mean $\pm \mathrm{SD}(n=4-5) .{ }^{*} P<0.05$ vs. no compound in J2N-k hamsters. 
Jolla, CA, USA). Ruthenium red was obtained from Wako Pure Chemical Industries Ltd. (Osaka, Japan). 2-[(2E)-3-(3-Chloro-4,5-dimethoxyphenyl)-2-cyanoprop2-enoylamino]benzoic acid (A3) (NATR020256) and 1-\{2-[3-((1E)-2-(1,2,4-triazol-4-yl)-2-azavinyl)indolyl] ethoxy\}-3-methoxybenzene (B6) (NATR030155) were purchased from Vitas-M Laboratory, Ltd. (Apeldoorn, the Netherlands). (2E)-3-(3,4-Dimethoxyphenyl)-N-(2nitrophenyl)prop-2-enamide (A63) (OSSK-422912), 4,5-dimethoxy-2-(phenylureido)benzoic acid (A65) (OSSK-423626), and 1-indolizin-2-yl-4-methoxybenzene (B33) (OSSK-004571) were obtained from Princeton University. 4,4'-[3-[2-[1-ethyl-4(1H)-quinolinylidene] ethylidene]-1-propene-1,3-diyl]bis(1-ethylquinolinium) diiodide (lumin) was kindly provided by Hayashibara Biochemical Laboratories (Okayama, Japan). Fura-2acetoxymethylester (AM) was obtained from Dojindo Laboratories (Kumamoto, Japan). All chemicals used in the study were of the highest available purity.

\section{Molecular biology}

Plasmid constructs of TRPV2, TRPV1, and transient receptor potential cation channel, subfamily $\mathrm{C}$, member 1 (TRPC1) were generated using a PCR-based strategy from full-length cDNA sequences of mTRPV2 and hTRPV2, hTRPV1, and hTRPC1 cloned into the pIRES expression vector (Clontech Laboratories, Mountain View, CA, USA).

\section{Cell culture}

Myocytes were cultured from enzymatically dissociated muscles of $\mathrm{J} 2 \mathrm{~N}-\mathrm{n}$ and $\mathrm{J} 2 \mathrm{~N}-\mathrm{k}$ hamsters as previously described [39]. Briefly, satellite cells were obtained from the gastrocnemius muscle using an enzyme cocktail containing $0.5 \mathrm{mM} \mathrm{CaCl}_{2}$. After enrichment of myoblasts by preplating over several rounds, cells were seeded in culture dishes. Two days after seeding, the culture medium was replaced with Dulbecco's modified Eagle's medium (DMEM) containing 2\% horse serum to induce myotube formation. Myocytes were analysed 2-4 days after the start of fusion.

HEK293 and CHO cells were maintained in DMEM (containing $25 \mathrm{mM} \mathrm{NaHCO}_{3}$ and supplemented with $7.5 \%$ (v/v) foetal calf serum) and transfected with cDNA using Lipofectamine $^{\circledR} 2000$ (Invitrogen). Stable clones were isolated by puromycin selection (Nacalai Tesque, Inc., Kyoto, Japan).

\section{$\left[\mathrm{Ca}^{2+}\right]_{\mathrm{i}}$ measurement}

$\left[\mathrm{Ca}^{2+}\right]_{\mathrm{i}}$ was measured by a ratiometric fluorescence method as previously described [17]. Briefly, HEK293 cells were loaded with $4 \mu \mathrm{M}$ fura-2-AM for $30 \mathrm{~min}$ at $37^{\circ} \mathrm{C}$ and maintained in balanced salt solution (BSS) (146 mM $\mathrm{NaCl}, 4 \mathrm{mM} \mathrm{KCl}, 2 \mathrm{mM} \mathrm{MgCl}$, $0.5 \mathrm{mM} \mathrm{CaCl}_{2}, 10 \mathrm{mM}$ glucose, $0.1 \%$ bovine serum albumin, and $10 \mathrm{mM}$ HEPES/
Tris, $\mathrm{pH}$ 7.4). Fura-2-AM fluorescence was measured using an Aquacosmos fluorescence image processor (Hamamatsu Photonics, Hamamatsu, Japan). The timecourse data are presented as the ratio of fluorescence at an excitation wavelength of $340 \mathrm{~nm}$ to that at $380 \mathrm{~nm}$. The increase in the fluorescence ratio induced by the TRPV2 agonist 2-APB or high extracellular $\mathrm{Ca}^{2+}(\Delta \mathrm{R})$ was normalized to the initial ratio $\left(\mathrm{R}_{0}\right)$ before stimulation. The fluorescence relative ratio $\left(\Delta R / R_{0}\right)$ was plotted as the summary data in the fluorescence imaging analysis.

For screening, cells were plated in 96-well plates and the fura-2-AM fluorescence ratio at excitation wavelengths of $340 \mathrm{~nm}$ and $380 \mathrm{~nm}$ was monitored using a GENios Pro microplate reader (Tecan, Research Triangle Park, NC, USA) or POLARstar Omega (BMG Labtech, Germany). Cells were stimulated in BSS containing $5 \mathrm{mM}$ $\mathrm{CaCl}_{2}$. For stimulation with 2-APB $(0.5 \mathrm{mM})$, the $\mathrm{pH}$ was adjusted to 6.5. All $\mathrm{Ca}^{2+}$ measurements were carried out at room temperature. Because the experimental conditions (filter setting, slit length, etc.) for the microplate reader analysis were different from those used in the fluorescence imaging analysis, these experiments produced different $340 / 380 \mathrm{~nm}$ fluorescence ratios. For simplicity, the results are presented as normalized values ( $\%$ maximum) from the microplate reader experiment.

\section{Electrophysiology}

TRPV2 currents were recorded under voltage-clamp conditions by the whole-cell patch-clamp technique [40]. Patch pipettes (2-5 M $\Omega$ ) were filled with an intracellular solution containing $110 \mathrm{mM} \mathrm{K}$-aspartate, $30 \mathrm{mM} \mathrm{KCl}$, $10 \mathrm{mM} \mathrm{NaCl}, 1 \mathrm{mM} \mathrm{MgCl}, 10 \mathrm{mM}$ BAPTA, $10 \mathrm{mM}$ HEPES, and $3 \mathrm{mM} \mathrm{MgATP}$ (adjusted to $\mathrm{pH} 7.2$ with $\mathrm{KOH})$. The extracellular solution contained $145 \mathrm{mM}$ $\mathrm{NaCl}, 5 \mathrm{mM} \mathrm{KCl}, 1.5 \mathrm{mM} \mathrm{MgCl}, 1 \mathrm{mM}$ EGTA, $10 \mathrm{mM}$ HEPES, and $10 \mathrm{mM}$ glucose ( $\mathrm{pH}$ was adjusted to 6.5 with $\mathrm{NaOH}$ ). Because TRPV2 was reported to desensitize in the presence of extracellular $\mathrm{Ca}^{2+}$ [41], we used nominally $\mathrm{Ca}^{2+}$-free medium containing $1 \mathrm{mM}$ EGTA to prevent desensitization. In the experiments confirming the $\mathrm{pH}$ dependence of the response, the $\mathrm{pH}$ was adjusted to 7.4. In the whole-cell recordings, the membrane potential of the cell was held at $-60 \mathrm{mV}$, while voltage ramps of $400 \mathrm{~ms}$ from $-100 \mathrm{mV}$ to $+60 \mathrm{mV}$ were applied every 2 seconds. Currents through the electrode were recorded at 5 $\mathrm{kHz}$ and filtered at $2 \mathrm{kHz}$ by an Axopatch 200B amplifier (Molecular Devices, LLC, Sunnyvale, CA, USA). The junctional potential was $-11.7 \mathrm{mV}$. We did not compensate for the junctional potential in the calculations.

For the measurement of L-type $\mathrm{Ca}^{2+}$ currents, human Cav1.2/ $\beta 2 / \alpha 2 \delta 1$ calcium channel expressing $\mathrm{CHO}$ cells were purchased from ChanTest (Cleveland, $\mathrm{OH}, \mathrm{USA}$ ). The holding potential was held at $-80 \mathrm{mV}$, while depolarizing pulses of $0 \mathrm{mV}$ for 200 milliseconds were applied every 10 seconds. The composition of the extracellular solution was as follows: $145 \mathrm{mM}$ 
$\mathrm{NaCl}, 4 \mathrm{mM} \mathrm{KCl}, 10 \mathrm{mM} \mathrm{CaCl}{ }_{2}, 10 \mathrm{mM}$ HEPES, and $10 \mathrm{mM}$ glucose (adjusted to $\mathrm{pH} 7.4$ with $\mathrm{NaOH}$ ). The composition of the intracellular solution was as follows: $112 \mathrm{mM}$ CsCl, $27 \mathrm{mM}$ CsF, 2 mM NaCl, 8.2 mM EGTA, $10 \mathrm{mM}$ HEPES, and $4 \mathrm{mM}$ MgATP (adjusted to $\mathrm{pH} 7.2$ with $\mathrm{CsOH}$ ). The data were analysed and plotted with Clampfit 9 (Molecular Devices, LLC, Sunnyvale, CA, USA). All experiments were performed at temperatures between $22^{\circ} \mathrm{C}$ and $25^{\circ} \mathrm{C}$.

\section{Application of mechanical stretch to myocytes}

Mechanical stretch was applied to myocytes using a chamber described in a previous study [42]. A silicon chamber with a transparent bottom (200 $\mu \mathrm{m}$ thickness) was attached to a stretching apparatus (NS-300; SCHOLARTEC Co., Osaka, Japan) driven by a computer-controlled stepping motor. Cells were allowed to attach to the chamber bottom for the indicated times. A constant, monoaxial sinusoidal stretch was applied from 5\% to $20 \%$ elongation at $1 \mathrm{~Hz}$, producing uniform elongation of the silicon membrane across the membrane area. Experiments were performed at $25^{\circ} \mathrm{C} \pm 1^{\circ} \mathrm{C}$.

\section{In silico ligand screening}

The Namiki 2004 chemical library (Namiki Shoji Co., Ltd., Tokyo, Japan) was used to select 350 compounds via ligand-based virtual screening [43]. The previously reported active ligands tranilast and SKF96365 were used as reference molecules. Chemical structures were represented as molecular descriptors using the DRAGONX v.1.2 program (Talete S.r.l., Milan, Italy). The 350 top-ranked compounds were selected based on their similarity to the reference molecules as measured by the Tanimoto coefficient.

\section{Assays and data analysis}

Creatine phosphokinase (CK) activity in the medium was determined using an in vitro colorimetric assay kit (CK Test Kit; Wako Pure Chemical Industries, Ltd., Osaka, Japan) according to the manufacturer's protocol The cTN-I level in the serum was measured, while quantitative immunoblotting and immunocytochemistry were performed as previously described [38, 39]. Protein concentration was measured using the bicinchoninic acid assay (Pierce Chemical Co., Rockford, IL, USA) with bovine serum albumin as the standard. All histochemical and physiological analyses were performed by investigators blinded to the drug treatments. Unless otherwise stated, results are presented as the mean \pm SD of at least 5 determinations. The unpaired Student's $t$-test and one-way ANOVA followed by Dunnett's test were used to analyse the data. Values of $P<0.05$ (indicated as asterisks in the figures) were considered statistically significant. All cellular measurements were repeated at least 5 times. Representative data are shown.

\section{Abbreviations}

A3: 2-[(2E)-3-(3-chloro-4:5-dimethoxyphenyl)2-cyanoprop-2-enoylamino]benzoic acid; A48: 2-[(4-methoxyphenyl)carbonylamino]-3-methylbenzoic acid; A63: (2E)-3-(3:4-dimethoxyphenyl)-N-(2-nitrophenyl) prop-2-enamide; A65: 4:5-dimethoxy-2-(phenylureido) benzoic acid; AM: acetoxymethylester; 2-APB: 2-aminoethoxydiphenylborate; B6: 1-\{2- [3-((1E)-2-(1:2:4triazol-4-yl)-2-azavinyl)indolyl]ethoxy $\}$-3-methoxybenzene; B33: 1-indolizin-2-yl-4-methoxybenzene; BSS: balanced salt solution; cTN: cardiac troponin; $\left[\mathrm{Ca}^{2+}\right]_{\mathrm{i}}$ : cytosolic (intracellular) $\mathrm{Ca}^{2+}$ concentration; $\mathrm{CK}$ : creatine phosphokinase; DCM: dilated cardiomyopathy; DMEM: Dulbecco's modified Eagle's medium; EF: ejection fraction; FS: fractional shortening; lumin: 4:4'-[3-[2-[1-ethyl-4(1H)-quinolinylidene] ethylidene]-1-propene-1:3-diyl]bis(1-ethylquinolinium)

diiodide; LVDd: left ventricular end-diastolic dimension; LVDs: left ventricular end-systolic dimension; SG: sarcoglycan; SKF96365: 1-[ $\beta$-[3-(4-methoxyphenyl) propoxy]-4-methoxyphenethyl]-1H-imidazole; tranilast: N-[3:4-dimethoxycinnamonyl]-anthranilic acid; TRPV: transient receptor potential cation channel: subfamily $\mathrm{V}$ (vanilloid); TRPC: transient receptor potential cation channel: subfamily C (canonical).

\section{Author contributions}

Y.I. and S.W. planned the majority of the experiments and wrote the paper. Y.I. executed most of the experiments. Y.K. executed the electrophysiological experiments. Y.O. selected the compounds using in silico methods.

\section{ACKNOWLEDGMENTS AND FUNDING}

The authors thank Ms. H. Ohtake and M. Hirayama for technical assistance. This work was supported by a Grantin-Aid for Priority Areas (no. 18077015 to S.W.); Grantsin-Aid (nos. 19390080 and 17659241 to S.W. and nos. 18590796, 20590874, and 17K09598 to Y.I.); a Grant-inAid for Exploratory Research (no. 22659046 to S.W.) from the Japanese Ministry of Education, Culture, Sports, Science and Technology; a grant for the Promotion of Fundamental Studies in Health Sciences from the National Institute of Biomedical Innovation; research grants for Cardiovascular Diseases (no.17A-1 to S.W.) and Nervous and Mental Disorders (nos. 16B-2, 19A-7, 25-5, and 28-6 to Y.I.) from the Japanese Ministry of Health, Labour and Welfare.

\section{CONFLICTS OF INTEREST}

None. 


\section{Editorial note}

This paper has been accepted based in part on peerreview conducted by another journal and the authors' response and revisions as well as expedited peer-review in Oncotarget.

\section{REFERENCES}

1. Hughes SE, McKenna WJ. New insights into the pathology of inherited cardiomyopathy. Heart. 2005; 91:257-264.

2. Fatkin D, Graham RM. Molecular mechanisms of inherited cardiomyopathies. Physiological Reviews. 2002; 82:945-980

3. Seidman JG, Seidman C. The genetic basis for cardiomyopathy: from mutation identification to mechanistic paradigms. Cell. 2001; 104:557-567.

4. Duclos F, Straub V, Moore SA, Venzke DP, Hrstka RF, Crosbie RH, Durbeej M, Lebakken CS, Ettinger AJ, van der Meulen J, Holt KH, Lim LE, Sanes JR, et al. Progressive muscular dystrophy in alpha-sarcoglycan-deficient mice. The Journal of Cell Biology. 1998; 142:1461-1471.

5. Campbell KP. Three muscular dystrophies: loss of cytoskeleton-extracellular matrix linkage. Cell. 1995; 80:675-679.

6. Nigro V, Okazaki Y, Belsito A, Piluso G, Matsuda Y, Politano L, Nigro G, Ventura C, Abbondanza C, Molinari AM, Acampora D, Nishimura M, Hayashizaki Y, et al. Identification of the Syrian hamster cardiomyopathy gene. Human Molecular Genetics. 1997; 6:601-607.

7. Campbell KP, Kahl SD. Association of dystrophin and an integral membrane glycoprotein. Nature. 1989; 338:259-262.

8. Tinsley JM, Blake DJ, Zuellig RA, Davies KE. Increasing complexity of the dystrophin-associated protein complex. Proceedings of the National Academy of Sciences of the United States of America. 1994; 91:8307-8313.

9. Ervasti JM, Campbell KP. A role for the dystrophin-glycoprotein complex as a transmembrane linker between laminin and actin. The Journal of Cell Biology. 1993; 122:809-823.

10. Mallouk N, Jacquemond V, Allard B. Elevated subsarcolemmal $\mathrm{Ca}^{2+}$ in $\mathrm{mdx}$ mouse skeletal muscle fibers detected with $\mathrm{Ca}^{2+}$-activated $\mathrm{K}^{+}$channels. Proc Natl Acad Sci U S A. 2000; 97:4950-4955.

11. Michalak M, Opas M. Functions of dystrophin and dystrophin associated proteins. Curr Opin Neurol. 1997; 10:436-442.

12. Robert V, Massimino ML, Tosello V, Marsault R, Cantini $\mathrm{M}$, Sorrentino V, Pozzan T. Alteration in calcium handling at the subcellular level in mdx myotubes. J Biol Chem. 2001; 276:4647-4651.

13. Franco A Jr, Lansman JB. Calcium entry through stretchinactivated ion channels in mdx myotubes. Nature. 1990; 344:670-673.
14. Fong PY, Turner PR, Denetclaw WF, Steinhardt RA. Increased activity of calcium leak channels in myotubes of Duchenne human and mdx mouse origin. Science. 1990; 250:673-676.

15. Nakamura TY, Iwata Y, Sampaolesi M, Hanada H, Saito N, Artman M, Coetzee WA, Shigekawa M. Stretch-activated cation channels in skeletal muscle myotubes from sarcoglycan-deficient hamsters. Am J Physiol Cell Physiol. 2001; 281:C690-699.

16. Iwata Y, Katanosaka Y, Arai Y, Komamura K, Miyatake K, Shigekawa M. A novel mechanism of myocyte degeneration involving the $\mathrm{Ca}^{2+}$-permeable growth factor-regulated channel. The Journal of Cell Biology. 2003; 161:957-967.

17. Iwata Y, Katanosaka Y, Arai Y, Shigekawa M, Wakabayashi S. Dominant-negative inhibition of $\mathrm{Ca}^{2+}$ influx via TRPV2 ameliorates muscular dystrophy in animal models. Human Molecular Genetics. 2009; 18:824-834.

18. Zanou N, Iwata Y, Schakman O, Lebacq J, Wakabayashi S, Gailly P. Essential role of TRPV2 ion channel in the sensitivity of dystrophic muscle to eccentric contractions. FEBS Lett. 2009; 583:3600-3604.

19. Iwata Y, Ohtake H, Suzuki O, Matsuda J, Komamura K, Wakabayashi S. Blockade of sarcolemmal TRPV2 accumulation inhibits progression of dilated cardiomyopathy. Cardiovasc Res. 2013; 99:760-768.

20. Suzuki O, Kanai T, Nishikawa T, Yamam oto Y, Noguchi A, Takimoto K, Koura M, Noguchi Y, Uchio-Yamada K, Tsuji $\mathrm{S}$, Matsuda J. Adult onset cardiac dilatation in a transgenic mouse line with Gal $\beta 1,3$ GalNAc $\alpha 2,3$-sialyltransferase II (ST3Gal-II) transgenes: a new model for dilated cardiomyopathy. Proc Jpn Acad Ser B Phys Biol Sci. 2011; 87:550-562.

21. Juvin V, Penna A, Chemin J, Lin YL, Rassendren FA. Pharmacological characterization and molecular determinants of the activation of transient receptor potential V2 channel orthologs by 2-aminoethoxydiphenyl borate. Mol Pharmacol. 2007; 72:1258-1268.

22. Nie L, Oishi Y, Doi I, Shibata H, Kojima I. Inhibition of proliferation of MCF-7 breast cancer cells by a blocker of $\mathrm{Ca}(2+)$-permeable channel. Cell Calcium. 1997; 22:75-82.

23. Schwarz G, Droogmans G, Nilius B. Multiple effects of SK\&F 96365 on ionic currents and intracellular calcium in human endothelial cells. Cell Calcium. 1994; 15:45-54.

24. Clapham DE, Runnels LW, Strubing C. The TRP ion channel family. Nat Rev Neurosci. 2001; 2:387-396.

25. Kunikata T, Ishihara T, Ushio S, Iwaki K, Ikeda M, Kurimoto M. Lumin, a cyanine dye, enhances interleukin 12-dependent interferon gamma production by lipopolysaccharidestimulated mouse splenocytes. Biological \& Pharmaceutical Bulletin. 2002; 25:1018-1021.

26. Monet M, Gkika D, Lehen'kyi V, Pourtier A, Vanden Abeele F, Bidaux G, Juvin V, Rassendren F, Humez S, Prevarsakaya N. Lysophospholipids stimulate prostate cancer cell migration via TRPV2 channel activation. Biochim Biophys Acta. 2009; 1793:528-539. 
27. Bang S, Kim KY, Yoo S, Lee SH, Hwang SW. Transient receptor potential V2 expressed in sensory neurons is activated by probenecid. Neurosci Lett. 2007; 425:120-125.

28. Qin N, Neeper MP, Liu Y, Hutchinson TL, Lubin ML, Flores CM. TRPV2 is activated by cannabidiol and mediates CGRP release in cultured rat dorsal root ganglion neurons. J Neurosci. 2008; 28:6231-6238.

29. Koch SE, Gao X, Haar L, Jiang M, Lasko VM, Robbins N, Cai W, Brokamp C, Varma P, Tranter M, Liu Y, Ren X, Lorenz JN, et al. Probenecid: novel use as a non-injurious positive inotrope acting via cardiac TRPV2 stimulation. J Mol Cell Cardiol. 2012; 53:134-144.

30. Rubinstein J, Lasko VM, Koch SE, Singh VP, Carreira V, Robbins N, Patel AR, Jiang M, Bidwell P, Kranias EG, Jones WK, Lorenz JN. Novel role of transient receptor potential vanilloid 2 in the regulation of cardiac performance. Am J Physiol Heart Circ Physiol. 2014; 306:H574-584.

31. Chung MK, Lee H, Mizuno A, Suzuki M, Caterina MJ. 2-aminoethoxydiphenyl borate activates and sensitizes the heat-gated ion channel TRPV3. J Neurosci. 2004; 24:5177-5182.

32. Caterina MJ, Rosen TA, Tominaga M, Brake AJ, Julius D. A capsaicin-receptor homologue with a high threshold for noxious heat. Nature. 1999; 398:436-441.

33. Mihara H, Boudaka A, Shibasaki K, Yamanaka A, Sugiyama $\mathrm{T}$, Tominaga $\mathrm{M}$. Involvement of TRPV2 activation in intestinal movement through nitric oxide production in mice. J Neurosci. 2010; 30:16536-16544.

34. Harisseh R, Chatelier A, Magaud C, Deliot N, Constantin B. Involvement of TRPV2 and SOCE in calcium influx disorder in DMD primary human myotubes with a specific contribution of alpha1-syntrophin and PLC/PKC in SOCE regulation. Am J Physiol Cell Physiol. 2013; 304:C881-894.

35. Katanosaka Y, Iwasaki K, Ujihara Y, Takatsu S, Nishitsuji K, Kanagawa M, Sudo A, Toda T, Katanosaka K, Satoshi M,
Naruse K. TRPV2 is critical for the maintenance of cardiac structure and function in mice. Nat Commun. 2014; 5:3932.

36. Yamamoto N, Homma S, Nakagawa Y, Hayami M, Imanaga H, Kurimoto M, Mitsuhashi M, Kimoto T. Activation of mouse macrophages by in vivo and in vitro treatment with a cyanine dye, lumin. Journal of Photochemistry and Photobiology B: Biology. 1992; 13:295-306.

37. Mito K. Photodynamic efficiency of macrophage activity using a photosensitizer, lumin, with near-IR laser light for photoimmunotherapy of a cancer. Frontiers of Medical and Biological Engineering. 1996; 7:81-92.

38. Nakamura TY, Iwata Y, Arai Y, Komamura K, Wakabayashi $\mathrm{S}$. Activation of $\mathrm{Na}^{+} / \mathrm{H}^{+}$exchanger 1 is sufficient to generate $\mathrm{Ca}^{2+}$ signals that induce cardiac hypertrophy and heart failure. Circulation Research. 2008; 103:891-899.

39. Iwata Y, Katanosaka Y, Shijun Z, Kobayashi Y, Hanada H, Shigekawa M, Wakabayashi S. Protective effects of $\mathrm{Ca}^{2+}$ handling drugs against abnormal $\mathrm{Ca}^{2+}$ homeostasis and cell damage in myopathic skeletal muscle cells. Biochem Pharmacol. 2005; 70:740-751.

40. Hamill OP, Marty A, Neher E, Sakmann B, Sigworth FJ. Improved patch-clamp techniques for high-resolution current recording from cells and cell-free membrane patches. Pflugers Arch. 1981; 391:85-100.

41. Mercado J, Gordon-Shaag A, Zagotta WN, Gordon SE. $\mathrm{Ca}^{2+}$-dependent desensitization of TRPV2 channels is mediated by hydrolysis of phosphatidylinositol 4,5-bisphosphate. J Neurosci. 2010; 30:13338-13347.

42. Naruse K, Sokabe M. Involvement of stretch-activated ion channels in $\mathrm{Ca}^{2+}$ mobilization to mechanical stretch in endothelial cells. Am J Physiol. 1993; 264:C1037-1044.

43. Yabuuchi $H$, Niijima $S$, Takematsu $H$, Ida $T$, Hirokawa $T$, Hara T, Ogawa T, Minowa Y, Tsujimoto G, Okuno Y. Analysis of multiple compound-protein interactions reveals novel bioactive molecules. Mol Syst Biol. 2011; 7:472. 